\title{
Slaughterhouse wastewater treatment in a bamboo ring anaerobic fixed-bed reactor
}

\author{
Wolfgang P. Tritt ${ }^{1}$, Ho Kang ${ }^{+}$ \\ ${ }^{1}$ ENVITEC, Ingenieur und Projektentwicklungsgesellschaft, mbH \& Co. KG, Weser str. 30, D-31737 Rinteln, Germany \\ ${ }^{2}$ Department of Environmental Engineering, Chungnam National University, Daejeon 34134, Republic of Korea
}

\begin{abstract}
A pilot scale anaerobic fixed-bed with a reactor volume of $2.8 \mathrm{~m}^{3}$ was built to treat slaughterhouse wastewater. Bamboo rings were chosen as support media mainly because of their cheaper price in underdeveloped countries. Even with their lower porosity and specific surface, the reactor performance showed a maximum 95\% COD removal efficiency at an organic loading rate (OLR) of $1 \mathrm{~kg}$ COD/ $\mathrm{m}^{3}-\mathrm{d}$ with its corresponding hydraulic retention time (HRT) of $7.5 \mathrm{~d}$. At a higher OLR of $4.0 \mathrm{~kg}$ COD/ $\mathrm{m}^{3}$-d, the COD removal efficiency of $75 \%$ was achieved with an HRT of $2 \mathrm{~d}$. No big difference in COD removal efficiencies was found between the reactors operated in both upflow and downflow modes. Their operational behavior and effluent characteristics were similar. The effluent COD/TKN ratio of 6.67 at an OLR of $4.0 \mathrm{~kg}$ COD/ $\mathrm{m}^{3}-\mathrm{d}$ was only marginal acceptable range for a subsequent biological denitrification process. Otherwise carbon supplementation is required at a lower OLR.
\end{abstract}

Keywords: Anaerobic fixed-bed, Bamboo rings, COD/TKN ratio, OLR, Slaughterhouse wastewater

\section{Introduction}

Slaughterhouse wastewater is generally characterized by a highly complex substrate. The amount of wastewater and its relevant organic loading vary widely among slaughterhouses since they depend not only on the degree of further processing of the slaughted animals, the stomachs, rumen and intestines in the tripery, but on the primary treatment options to separate liquid from the solid residues. An average COD concentration ranges from $8,000-20,000 \mathrm{mg} / \mathrm{L}$. The $\mathrm{COD} / \mathrm{BOD}_{5}$ ratio is about 2.7 to 2.9 . The greater contribution to the organic loading is caused by blood, stomach and intestinal mucus. They contain carbohydrates, fats, proteins, volatile organic acids, amines, nitrogen compounds, etc.

There have been many experimental studies on the slaughterhouse wastewater treatment using anaerobic fixed-bed reactors. Anaerobic fixed-film reactor with PVC tubes as a support medium was used for poultry wastewater treatment achieving COD removal efficiency from $85 \%$ to $95 \%$ at an organic loading rates (OLRs) of $8 \mathrm{~kg} \mathrm{CODm}^{-3} \mathrm{~d}^{-1}$ [1]. In addition, in a full-scale fixed-bed reactor dealing with rendering wastewater of $70 \mathrm{t} / \mathrm{d}$ capacity with PVC tubes packed, COD removal efficiency was accomplished in the range $75-80 \%$ at an OLR $8 \mathrm{~kg} \mathrm{CODm}^{-3} \mathrm{~d}^{-1}$ [2]. A $7 \mathrm{~L}$ anaerobic fixed-bed reactor using Tezontle as a support medium showed COD removal efficiency of $81 \%$ [3]. In a lab-scale single reactor with the combination of sludge blanket and polyurethane foam filter, COD removal efficiency was between 90.2 and $93.4 \%$ at OLR from 2.49 to $20.82 \mathrm{~kg} \mathrm{CODm}^{-3} \mathrm{~d}^{-1}$ [4]. Another combination reactor, hybrid upflow anaerobic sludge blanket (HUASB), consisted of upflow anaerobic sludge blanket (UASB) and upflow anaerobic fiter (UAF) achieved COD removal efficiency of 80-92\% at OLR of $9.27 \mathrm{~kg} \mathrm{CODm}^{-3} \mathrm{~d}^{-1}$ [5].

Even though the study on the anaerobic fixed-bed reactor to treat slaughterhouse wastewater has not been studied extensively, Erdem operated upflow anaerobic fixed bed reactor using pumice stone as a support media and Abdurahman et al. utilized ultrasonic membrane for treating slaughterhouse wastewater [6, 7]. However, both studies were conducted based on the combined anaerobic digestion processes [8, 9].

There have been several options to deal with slaughterhouse wastewater. However, anaerobic biological treatment offers several significant advantages over other options, with regard to waste treatment and utilization. Among the anaerobic treatments an
This is an Open Access article distributed under the terms of the Creative Commons Attribution Non-Commercial License (http://creativecommons.org/licenses/by-nc/3.0/) which permits unrestricted non-commercial use, distribution, and reproduction in any medium, provided the original work is properly cited.
Received March 31, 2017 Accepted July 18, 2017

${ }^{\dagger}$ Corresponding author

Email: hokang@cnu.ac.kr

Tel: +82-42-821-6675 Fax: +82-42-822-5610

Copyright (C) 2018 Korean Society of Environmental Engineers 
anaerobic filter system is one of the best alternatives for such a diluted wastewater, since it can maintain higher active biomass concentration onto supporting media to achieve the maximum organic removal efficiency at a relatively short hydraulic retention time.

Various types of manufactured media are now available for replacement in anaerobic fixed bed reactors. This commercialized media have been found to be effective since they have very high porosity and high specific surface area. However, their cost may exceed \$100-150 / $/ \mathrm{m}^{3}$. Bamboo rings were chosen in this study as a supporting material even though they have lower porosity and lower specific surface, consequently require a larger reactor volume. However, their costs in underdeveloped countries, e.g. Indonesia, Malaysia, Philippines, are less than 5-10 percent of the costs of the commercialized media. Presently there are limited data available on the performance of anaerobic fixed-bed reactor using bamboo rings.

Prior to this study, Tritt examined a laboratory scale feasibility test of bamboo rings as a media to provide information necessary for running a full scale plant [10]. The maximum 85\% COD removal efficiency was achieved at an OLR of $2 \mathrm{~kg} / \mathrm{m}^{3}-\mathrm{d}$ with the hydraulic retention time (HRT) of $5 \mathrm{~d}$.

The goal of this research is to develop a highly efficient, pilot scale anaerobic fixed-bed reactor using bamboo rings. Specific objectives that will enable to achieve the goal are to; (1) determine the degree of pretreatment during the intermediate storage of slaughterhouse wastewater; (2) develope maximum organic removal kinetics using bamboo rings support media; (3) identify the baseline digestion kinetics at different operational mode (upflow and downflow modes); (4) ascertain the COD/TKN ratio of anaerobically pretreated wastewater suitable for a subsequent biological denitrification process.

\section{Materials and Methods}

\subsection{Substrate}

The slaughterhouse wastewater used in this experiment was obtained from the slaughterhouse in Braunschweig, Germany. This wastewater consisted of two different flows: one from the slaughtering process and the other from the tripery. The wastewater from the tripery passed through a grease trap. This wastewater was brought together in a sump before discharge to the municipal sewage system. Then the slaughterhouse wastewater was taken from the sump during cattle slaughtering, when all processes were running simultaneously. The COD wastewater was diluted with tap water and ended up to an average COD concentration

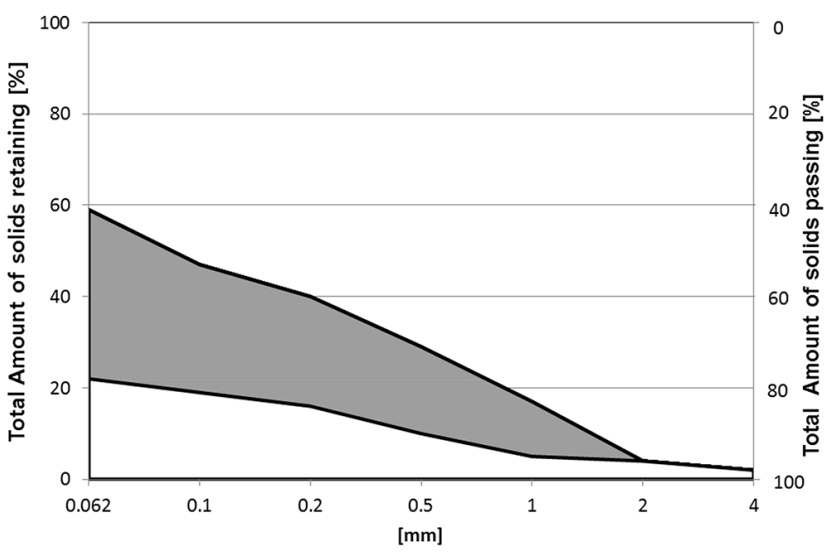

Fig. 1. Size distribution of solid particles in the slaughterhouse wastewater.

of 7,500 mg/L which used for the anaerobic fixed bed reactor. This average concentration was the result of the continuous monitoring for $72 \mathrm{~h}$. The size distribution of the solid particles in the slaughterhouse wastewater is shown in Fig. 1. 20-50 percent of the solid particles were retained on a screening whose opening was less than $0.1 \mathrm{~mm}$ in diameter.

\subsection{Inoculum}

The inoculum used in this pilot experiment was the effluent from a cattle manure continuously stirred tank reactor (CSTR) $\left(100 \mathrm{~m}^{3}\right.$ volume \& HRT $\left.=12.5 \mathrm{~d}\right)$. Before filling the fixed-bed reactor, the course solid particles were removed. Screen analyses showed that only $6 \%$ of the solid particles were retained on a screening whose diameter was greater than $1 \mathrm{~mm}$ and $66 \%$ of the solid particles were retained on a screening whose diameter was greater than $0.06 \mathrm{~mm}$. The screened inoculum contained TCOD of $50.3 \mathrm{~g} / \mathrm{L}$ (SCOD = $19.5 \mathrm{~g} / \mathrm{L}$ ) with $2.8 \%$ total solids (its TVS $=73 \%$ of TS). The $\mathrm{pH}$ was 7.8 .

\subsection{Support Media}

Bamboo rings were used as support media. Bamboo was obtained from Taiwan, and air dried (its TS $=89.5 \%$ ). The bamboo sticks were cut into rings whose size was $2.5 \mathrm{~cm}$ in length, 0.4-0.7 $\mathrm{cm}$ in width and 6-10 $\mathrm{cm}$ in inside diameter. Bamboo rings were randomly packed in the reactor. Characteristics of bamboo rings and commercially available support media are compared in Table 1. The specific surface and porosity of bamboo rings are relatively much lower than those of commercial packing media. Bamboo rings as bio-carriers are very affordable and almost free compared

Table 1. A Comparison of Characteristics of Bamboo Rings and Commercially Available Packing Materials

\begin{tabular}{|llcrr}
\hline Support media & Characteristics & Specific surface $\left(\mathbf{m}^{\mathbf{2}} / \mathbf{m}^{\mathbf{3}}\right)$ & Porosity $(\%)$ & Ref. \\
\hline Bamboo rings & $60-100$ mm bamboo rings & 89 & 88 & 97 \\
Hiflow rings & 90 mm plastic rings & 65 & 95 & {$[2]$} \\
Pall rings & 90 mm plastic rings & 102 & 320 & 97 \\
Flocor R & Corrugated rings & 148 & 96 & {$[2]$} \\
Plasdek C10 & Modular plastic blocks & {$[2]$} \\
\hline
\end{tabular}


to the cost of other packing materials (about 100-1,000 $\$ / \mathrm{m}^{3}$ ) [11] in underdeveloped countries of Southeast Asia.

\subsection{Pretreatment of Slaughterhouse Wastewater}

Two batch reactors were operated to examine changes in physical characteristics of slaughterhouse wastewater during the intermediate storage. Each reactor consisted of 20 liter volume and was open at constant temperatures of $10^{\circ} \mathrm{C}$ and $20^{\circ} \mathrm{C}$. Samples were taken at 2-3 d intervals for the parameter analyses.

\subsection{Pilot Scale Fixed-bed Reactor}

The schematic flow diagram of a $2.8 \mathrm{~m}^{3}$ pilot scale fixed-bed reactor filled with bamboo rings is illustrated in Fig. 2. Process relevant data on the fixed-bed reactor are given in Table 2. The content of the storage tank were mixed before and during feeding. The HRT was approximately 2-8 d, depending on the experimental schedule. The reactor was fed quasi-continuously every hour on the hour. The recirculation pump for effluent recycle was regulated

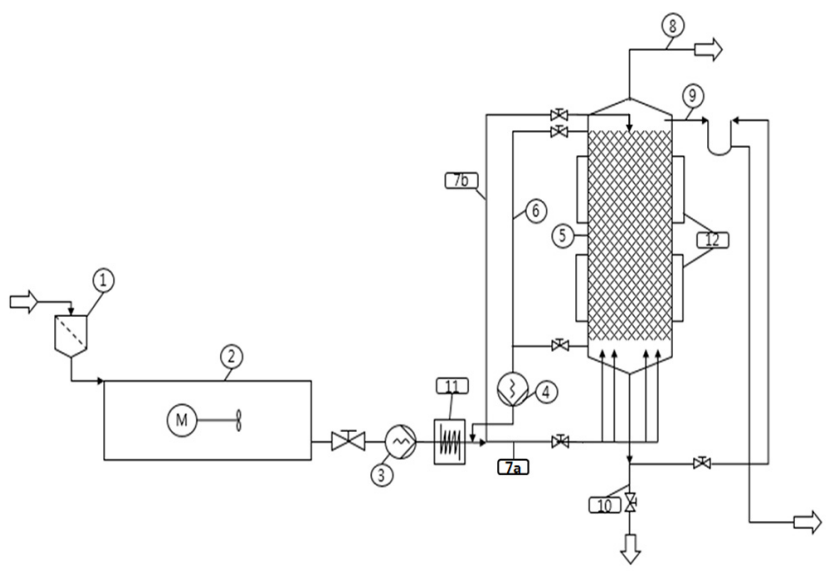

Fig. 2. A schematic flow diagram of the pilot-scale bamboo ring anaerobic fixed-bed reactor.

1. screen; 2. storage tank with agitator; 3 . feed pump; 4. recirculation pump; 5 . fixed-bed reactor; 6. recirculation pipe; 7a. reactor inflow (upflow operation); 7b. reactor inflow (downflow operation); 8. gas outlet pipe to gasmeter; 9. reactor outlet with siphon; 10 . sludge outlet; 11 . heat exchanger; 12 . jacket heater

Table 2. Process Relevant Data on the Bamboo Ring Anaerobic Fixed-bed Reactor

\begin{tabular}{|c|c|c|c|}
\hline Items & Unit & & \\
\hline Reactor volume $\left(\mathrm{V}_{\text {total }}\right)$ & $\mathrm{m}^{3}$ & & 2.8 \\
\hline Fixed-bed volume $\left(\mathrm{V}_{\mathrm{FB}}\right)$ & $\mathrm{m}^{3}$ & & 2.35 \\
\hline $\begin{array}{l}\text { Liquid volume }\left(\mathrm{V}_{\mathrm{F}}\right) \\
\text { at start of experiment }\end{array}$ & $\mathrm{m}^{3}$ & & 2.1 \\
\hline Support material & - & Bam & boo rings \\
\hline $\begin{array}{l}\text { Bamboo ring size } \\
\text { (Height and Diameter) }\end{array}$ & $\mathrm{cm}$ & $\mathrm{H}=2.5$ & $\mathrm{D}=6$ to 10 \\
\hline Porosity $\left(\mathrm{V}_{\mathrm{F}} / \mathrm{V}_{\mathrm{FB}}\right)$ & $\%$ & & 89 \\
\hline Specific surface & $\mathrm{m}^{2} / \mathrm{m}^{3}$ & & 88 \\
\hline
\end{tabular}

so that the rising velocity of the reactor content was kept constant 1.0 meter per hour. Following completion of the start-up phase, the reactor was run in upflow and downflow operation for approximately one year each, the loading rate being stepwise increased.

\subsection{Analytical Procedures}

All parameters were analyzed according to Standard Methods [4] except volatile organic acids and alkalinity. For the alkalinity measurement, sample were centrifuged to remove solids, and then titrated with $0.1 \mathrm{~N} \mathrm{H}_{2} \mathrm{SO}_{4}$ to $\mathrm{pH} 5.0$ and further titrated down to $\mathrm{pH}$ 4.4, respectively. Each concentration of volatile fatty acids (VFA) was also measured by a gas chromatograph (Mega 5340, Carlo Erba Instruments, France). The gas composition was determined with an infra-red gas analyzer (Maihak, SICK MAIHAK, Inc., Germany). All gas measurements were expressed in terms of standard temperature and pressure $\left(0^{\circ} \mathrm{C}, 760 \mathrm{~m} \mathrm{Hg}\right)$.

\section{Results and Discussion}

\subsection{Pretreatment of Wastewater}

The batch tests on the intermediate storage of slaughterhouse wastewater at the simulated temperature of $10^{\circ} \mathrm{C}$ and $20^{\circ} \mathrm{C}$ showed a low degree of acidification. As shown in Fig. 3, total volatile fatty acids (TVFA) rose from $247 / \mathrm{mg} / \mathrm{L}$ as acetic acid at the beginning of the experiment to a maximal value of $1,019 \mathrm{mg} / \mathrm{L}$ as acetic acid concentration at $20^{\circ} \mathrm{C}$ on day 3 . The production of VFA exceeded the extent which buffering capacity was formed during the first week of operation. Then the buffering capacity began to overtake VFA production and increased continuously to 1,000 $\mathrm{mg} / \mathrm{L}$ as $\mathrm{CaCO}_{3}$ at the end of the experiment. The production rate of the buffering capacity at $20^{\circ} \mathrm{C}$ was approximately two times higher than that at $10^{\circ} \mathrm{C}$ during the entire storage period. The continual increase in buffering capacity was mainly due to the methanation and mineralization of protein, which eventually

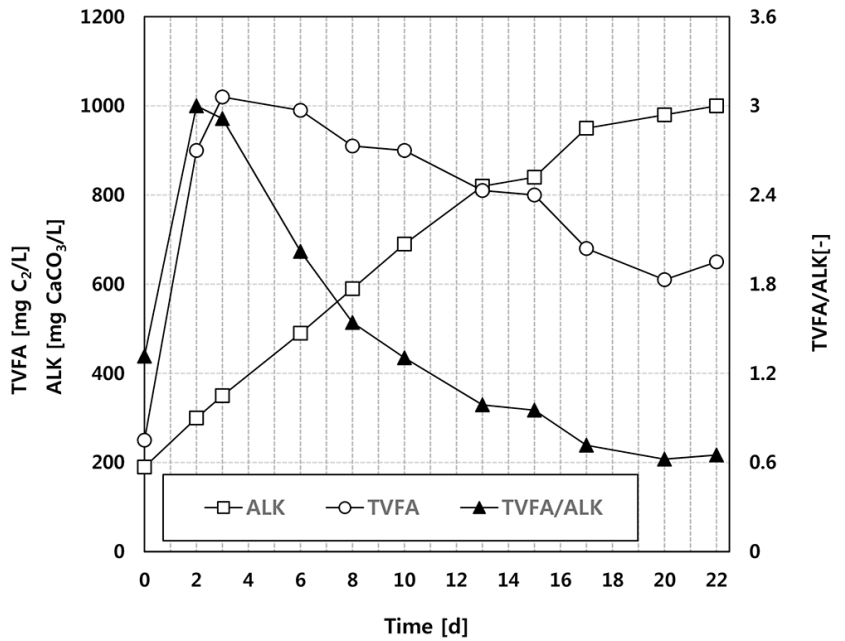

Fig. 3. Temporal variation of alkalinity (ALK), total volatile fatty acid (TVFA) and the ratio TVFA/ALK during the intermediate storage of slaughterhouse wastewater at $20^{\circ} \mathrm{C}$. 
led to the dynamics of carbonate and ammonia buffer systems in all storage reactors. These phenomena were also reflected by the ratio of TVFA and alkalinity (TVFA/ALK). The initial ratio of 1.41 sharply increased to a ratio of 2.91 within $3 \mathrm{~d}$ when the reactor was operated at $20^{\circ} \mathrm{C}$ and then dropped continuously until the end of storage period. The storage reactor took $9 \mathrm{~d}$ to recover the initial TVFA/ALK ratio. While the storage reactors when operated at $10^{\circ} \mathrm{C}$ took $13 \mathrm{~d}$.

Whatever anaerobic treatment processes are to be selected, the intermediate storage of waste and wastewater is required prior to feed to the main treatment process. It is therefore important to know about the changes in characteristics that occur in the substrate during the storage period. In the batch tests only a low degree of acidification was found during the first week of storage that is in a normal operational range of the hydraulic retention time for the anaerobic fixed-bed reactor with slaughterhouse wastewater. An obvious question still remains - the question whether such a low degree of acidification is beneficial to the methanation of slaughterhouse wastewater. However as the first stage of anaerobic fermentation, the controlled storage of slaughterhouse wastewater does not seem to be necessary for a highly efficient bamboo ring mesophilic anaerobic fixed-bed reactor.

\subsection{Start-up}

Initially the reactor was randomly packed with bamboo rings and then filled with $2.1 \mathrm{~m}^{3}$ of tap water up to the overflow outlet which was $2.8 \mathrm{~m}^{3}$. The bamboo rings had a porosity of $89 \%$ as measured by liquid volume in the media section of the reactor and a surface to volume ratio of $88 \%$. After $1 \mathrm{~d}$ soaking, $1 \mathrm{~m}^{3}$ of leaching water was drained, and $1 \mathrm{~m}^{3}$ of screened liquid manure was replaced as an inoculum. The gas production from inoculum itself was gradually increased and then reached stationary phase on day 11 which produced $1.37 \mathrm{~m}^{3}$ of biogas per day with a $\mathrm{CH}_{4}$ content of $68 \%$. The TVFA/ALK ratio at this point was 0.23 and thus indicated a good buffering capacity. Soluble organics leached from the soaking process might contribute to the reactor start-up period. The reactor loading started with $1 \mathrm{~kg}$ COD $/ \mathrm{m}^{3}-\mathrm{d}$ in an upflow mode. Reactors with upflow mode were documented to be faster in biofilm development than downflow reactors due to the lower washout effect of suspended biomass. The successful start-up operation was achieved within 2-3 weeks mainly because of larger size of inoculum utilized. When the reactor started with the OLR of $1 \mathrm{~kg} \mathrm{COD} / \mathrm{m}^{3}$-d, the substrate to inoculum ratio was approximately 0.06 as a total COD mass basis.

\subsection{Reactor Performance}

The COD removal efficiencies as a function of OLR are compared between upflow and downflow fixed bed reactors as illustrated in Fig. 4. It became clear that the COD removal efficiency of the upflow mode showed slightly higher than that of the downflow mode. However, the results were not comprehensive enough to draw any conclusion which operational mode is more suitable for the full scale plant operation of slaughterhouse wastewater. In general, the COD removal efficiencies decreased gradually as the organic loading rates increased. Conversely the COD removal efficiencies increased steadily at longer HRT as shown in Fig. 5.
The maximum COD removal of 95\% was achieved when the upflow fixed-bed reactor was operated at an OLR of $1 \mathrm{~kg} \mathrm{COD/}$ $\mathrm{m}^{3}$-d with its corresponding HRT of $7.5 \mathrm{~d}$. Contrarily the lowest COD removal efficiencies of $74 \%$ for the upflow mode and $72 \%$ for the downflow mode were obtained, respectively at an OLR of $4.0 \mathrm{~kg} \mathrm{COD} / \mathrm{m}^{3}-\mathrm{d}$ with its corresponding HRT of $1.9 \mathrm{~d}$.

The average methane gas yield (methane volume produced per reactor volume per day, v/v d) in both upflow and downflow reactors increased from $0.35 \mathrm{~m}^{3} / \mathrm{m}^{3}-\mathrm{d}$ at an OLR of $1 \mathrm{~kg} \mathrm{COD/}$ $\mathrm{m}^{3}$-d to $1.5 \mathrm{~m}^{3} / \mathrm{m}^{3}-\mathrm{d}$ when the OLR was raised to $4 \mathrm{~kg} \mathrm{COD/}$ $\mathrm{m}^{3}-\mathrm{d}$ as illustrated in Fig. 6. The methane content of the biogas ranged from $72-75 \%$ during the entire operation. Independently of the OLRs (OLR $=1-4 \mathrm{~kg} \mathrm{COD} / \mathrm{m}^{3}-\mathrm{d}$ ) or their corresponding HRTs (HRT $=2-8 \mathrm{~d}$ ), the reactor performance and its relevant operational behavior during the respective upflow and downflow operations are quite similar, as illustrated in Table 3. Reactor $\mathrm{pH}$ varied from 7.3 to 7.9 initially, but stayed above 7.7 for most of the operational period in both modes. The TVFA/ALK ratio of slaughterhouse wastewater was 1.45 with its alkalinity concentration of $590 \mathrm{mg} / \mathrm{L}$ as $\mathrm{CaCO}_{3}$. This ratio was reduced down to 0.15 with its corresponding alkalinity of $1,830 \mathrm{mg} / \mathrm{L}$ as $\mathrm{CaCO}_{3}$ at the end of operation. This indicates that over $90 \%$ of the reactor

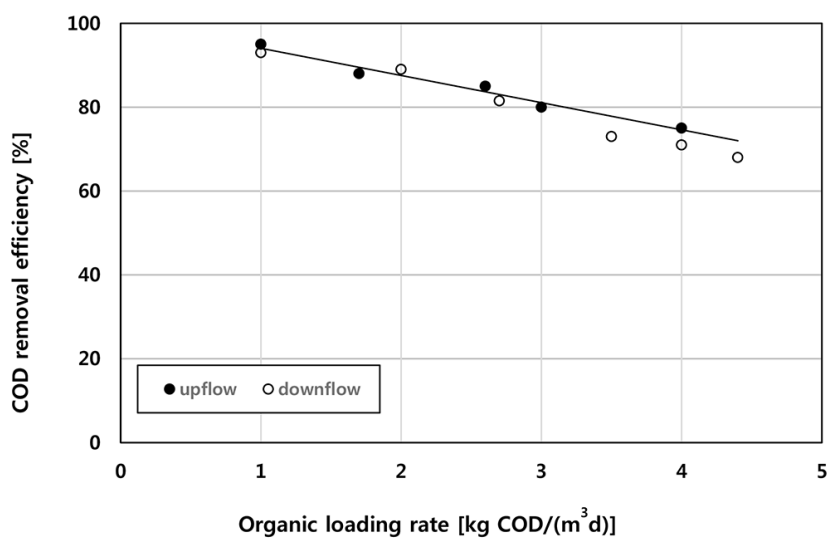

Fig. 4. COD removal efficiency as a function of organic loading rate.

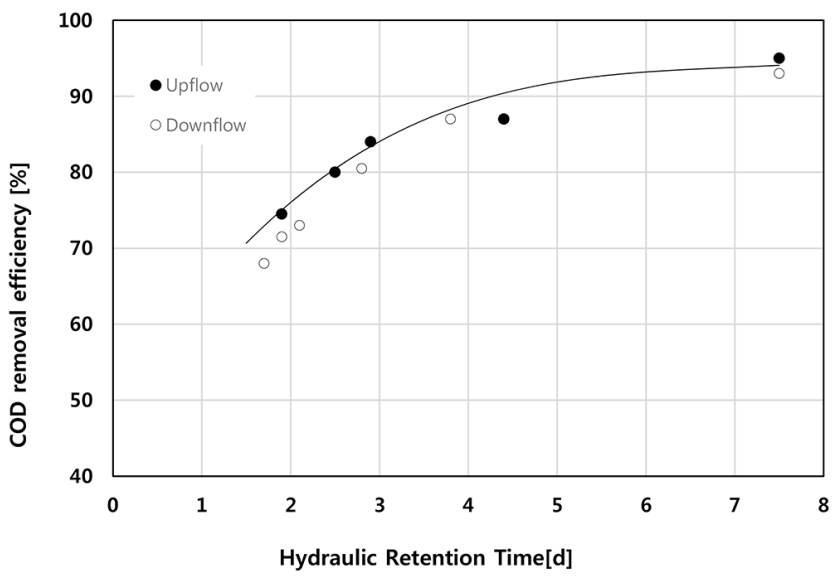

Fig. 5. COD removal efficiency as a function of hydraulic retention time. 
Table 3. A Summary of Performance in the Pilot Scale Anaerobic Fixed-bed Reactor with Upflow and Downflow Operations $\left(\mathrm{V}=2,8 \mathrm{~m}^{3}\right)$

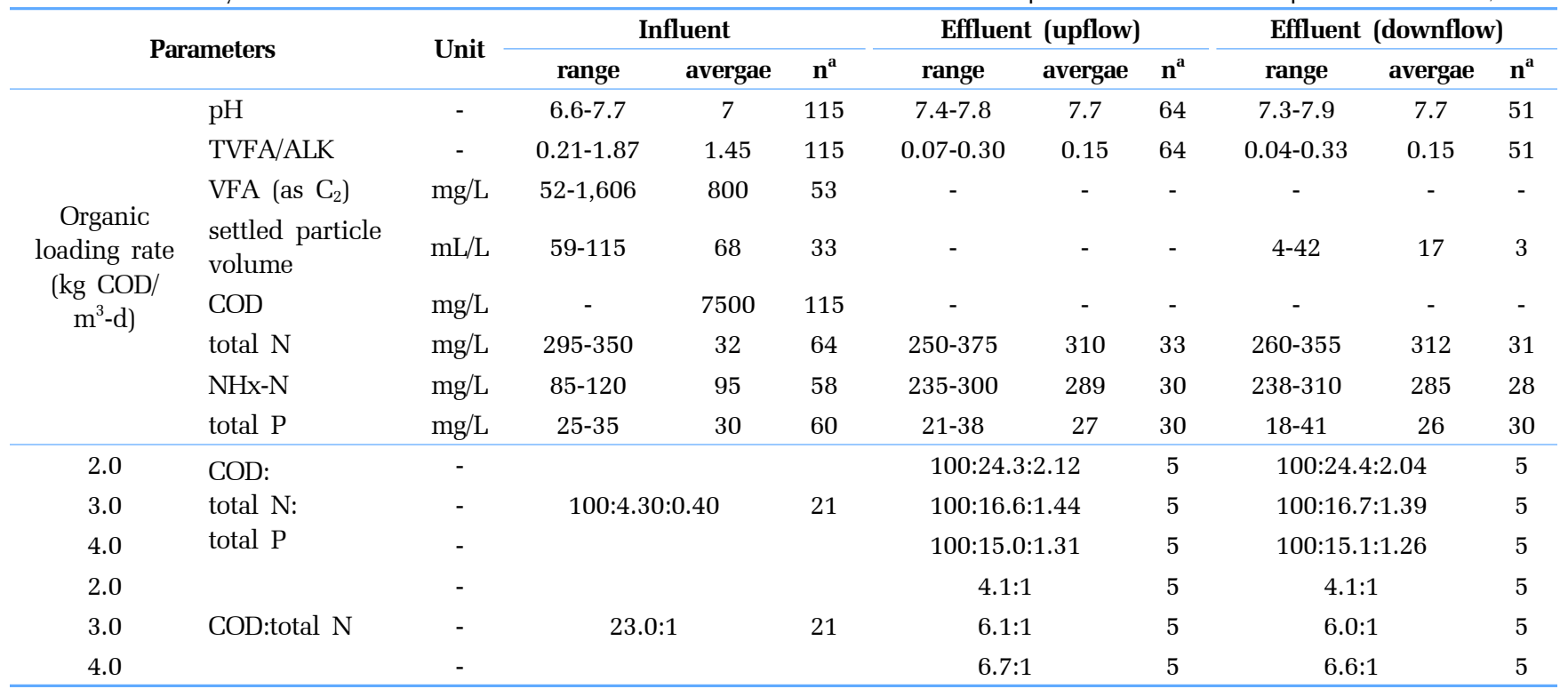

$\mathrm{n}^{\mathrm{a}}=$ number of samples analysed

Table 4. Organic Acid Concentration in the Influent and Effluent of the Bamboo Ring Anaerobic Fixed-bed Reactor (upflow operation)

\begin{tabular}{|c|c|c|c|c|c|c|}
\hline \multirow{2}{*}{ Organic Acids (as $\left.\mathrm{C}_{2} \mathrm{mg} / \mathrm{L}\right)^{\mathrm{a}}$} & \multicolumn{3}{|c|}{ Influent } & \multicolumn{3}{|c|}{ Effluent } \\
\hline & minimum & maximum & average & minimum & maximum & average \\
\hline acetic acid $\mathrm{C}_{2}$ & 10 & 668 & 277 & 12 & 478 & 120 \\
\hline propionic acid $\mathrm{C}_{3}$ & 17 & 368 & 226 & 7 & 105 & 30 \\
\hline isobutyric acid $\mathrm{i}-\mathrm{C}_{4}$ & 15 & 138 & 69 & 0 & 22 & 3 \\
\hline n-butyric acid $\mathrm{C}_{4}$ & 0 & 201 & 109 & 0 & 13 & 1 \\
\hline isovaleric acid $\mathrm{i}-\mathrm{C}_{5}$ & 0 & 173 & 86 & 0 & 22 & 2 \\
\hline n-valeric acid $\mathrm{C}_{5}$ & 0 & 58 & 33 & 0 & 0 & 0 \\
\hline caproic acid $\mathrm{C}_{6}$ & 0 & 0 & 0 & 0 & 0 & 0 \\
\hline Total & 43 & 1,606 & 800 & 19 & 640 & 156 \\
\hline
\end{tabular}

${ }^{a}$ Number of samples analyzed was 51 .

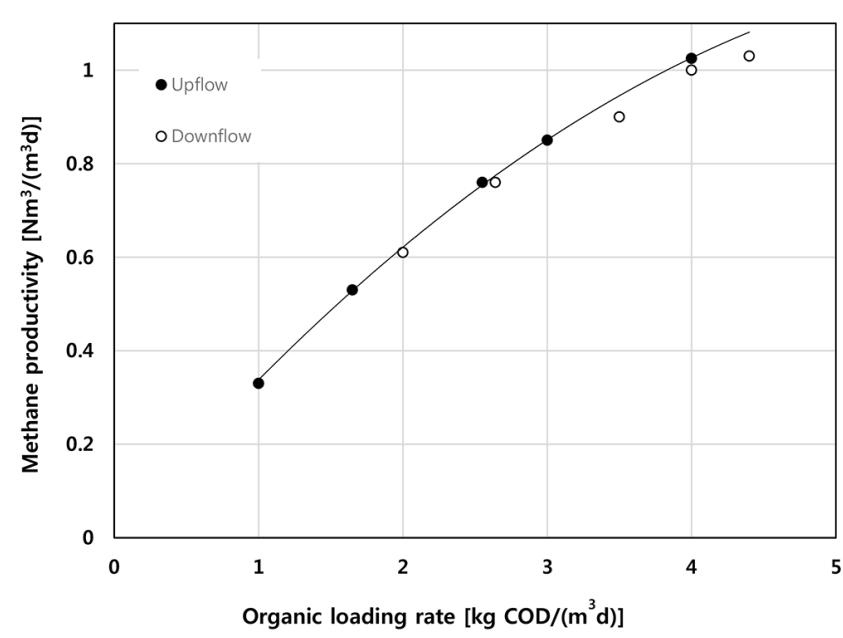

Fig. 6. Methaneproductivity as a function of organic loading rate. organic acids were completely buffered if the relative magnitude of organic acids and buffering capacity produced during the operational period were considered. The TVFA/ALK ratio depends on substrate characteristics, OLRs, solids retention times and overall reactor capability to convert organic acids to $\mathrm{CO}_{2}$ and $\mathrm{CH}_{4}$. However, this result shows that the ratio less than 0.3 has been a good indicator for the stable reactor operation with slaughterhouse wastewater [8]. The concentration of total volatile acids in the reactor influent and the acid spectrum were similar to those of batch test results. As shown in Table 4, the average total volatile fatty acid concentration of the reactor effluent was $156 \mathrm{mg} / \mathrm{L}$ as acetic acids concentration which remained much lower concentration. This could illustrate that hydrolysis reactions were rate limiting in the complex conversion process. Lower ratios of TVFA/ALK (0.04-0.33) observed during the entire operation also showed the hydrolysis limiting. The total nitrogen in the slaughterhouse wastewater consisted of approximately $71 \%$ of organic nitrogen and $29 \%$ of inorganic forms. During the anaerobic 
degradation process, about $85 \%$ of organic nitrogen was mineralized. This explained that why the ammonia nitrogen concentration increased from $95 \mathrm{mg} / \mathrm{L}$ in the influent to 289 and $285 \mathrm{mg} / \mathrm{L}$ in the effluents of downflow and upflow reactors, respectively. The ratio of COD : total nitrogen : total phosphorus in the treatment effluent was much narrower than that of influent mainly because of COD degradation in the reactor. However, there was no reduction in the total nitrogen during the operational period. Generally the magnitude of the ratio became narrower as the HRTs increased or the OLRs decreased. The BOD/TKN ratio is regarded as one of the most important parameters in designing a subsequent biological denitrification process. A minimum ratio 3.0 for the denitrification of domestic sewage was documented in ATV report [6]. The COD/TKN ratio of 6.0 in the effluent when the reactor OLR increased over $3.0 \mathrm{~kg} \mathrm{COD} / \mathrm{m}^{3}-\mathrm{d}$ was only marginal acceptable range. Otherwise carbon supplementation is required at a lower OLR.

\section{Conclusions}

A $2.8 \mathrm{~m}^{3}$ volume pilot scale anaerobic fixed-bed reactor was operated to treat slaughterhouse wastewater. Bamboo rings were chosen as packing materials mainly because of their cheaper price, compared to those of other commercial supporting media in underdeveloped countries. Even with their lower porosity and specific surface, the reactor performance showed a maximum 95\% COD removal efficiency at an OLR of $1 \mathrm{~kg} \mathrm{COD} / \mathrm{m}^{3}$-d with its corresponding HRT of $7.5 \mathrm{~d}$. At a higher OLR of $4.0 \mathrm{~kg} \mathrm{COD/} \mathrm{m}^{3}-\mathrm{d}$, the COD removal efficiency of $75 \%$ was achieved with an HRT of $2 \mathrm{~d}$. The average methane gas yield in both upflow and downflow reactors increased from $0.35 \mathrm{~m}^{3} / \mathrm{m}^{3}-\mathrm{d}$ at an OLR of $1 \mathrm{~kg} \mathrm{COD} / \mathrm{m}^{3}-\mathrm{d}$ to $1.5 \mathrm{~m}^{3} / \mathrm{m}^{3}$-d when the OLR was raised to $4 \mathrm{~kg} \mathrm{COD} / \mathrm{m}^{3}-\mathrm{d}$. The methane content of the biogas ranged from $72-75 \%$ during the entire operation. Independently of OLRs (1-4 $\left.\mathrm{kg} \mathrm{COD} / \mathrm{m}^{3}-\mathrm{d}\right)$ or their corresponding HRTs of 2-8 d, the reactor performance and its relevant operational behavior during the respective upflow and downflow operations are quite similar. The effluent COD/TKN ratio of 6.67 at an OLR of $4.0 \mathrm{~kg} \mathrm{COD} / \mathrm{m}^{3}-\mathrm{d}$ was only marginal acceptable range for a subsequent biological denitrification process. This study is expected to contribute to treat slaughterhouse wastewater, specifically in underdeveloped countries.

\section{Acknowledgments}

This work was carried out as a part of the R \& D project, "Biological
Treatment of Slaughterhouse Waste" sponsored by the German Federal Ministry of Research and Technology in the frame work of the scientific cooperation between Germany and Indonesia in the field of biotechnology.

\section{References}

1. del Pozo R, Diez V, Beltran S. Anaerobic pre-treatment of slaughterhouse wastewater using fixed-film reactors. Bioresour. Technol. 2000;71:143-149.

2. Metzner G, Temper U. Operation and optimization of full-scale fixed-bed reactor for anaerobic digestion of animal rendering wastewater. Water Sci. Technol. 1990;22:373-378.

3. Lopez-Lopez A, Vallejo-Rodriguez R, Mendez-Romero DC. Evaluation of a combined anaerobic and aerobic system for the treatment of slaughterhouse wastewater. Environ. Technol. 2010;31:319-326.

4. Borja R, Banks CJ, Wang Z, Mancha A. Anaerobic digestion of slaughterhouse wastewater using a combination sludge blanket and filter arrangement in a single reactor. Bioresour. Technol. 1997;65:125-133.

5. Rajakumar R, Meenambal T, Saravana PM, Ananthanarayanan P. Treatment of poultry slaughterhouse wastewater in hybrid upflow anaerobic sludge blanket reactor packed with pleated poly vinyl chloride rings. Bioresour. Technol. 2012;103:116-122.

6. Kocadagistan E. Treatment of slaughterhouse wastewater with upflow anaerobic pumice bed reactor. Life Sci. 2014;11:345-349.

7. Abdurahman NH, Rosli YM, Azhari NH. The potential of ultrasonic membrane anaerobic system (UMAS) in treating slaughterhouse wastewater. Asian Res. Publ. Network (ARPN) 2016;11:2653-2659.

8. Ware A, Power N. Biogas from cattle slaughterhouse waste: Energy recovery towards an energy self-sufficient industry in Ireland. Renew. Energ. 2016;97:541-549.

9. Samadi MT, Leili M, Haji Agha Alizadeh H, Godini K, Ahmadi F. Increasing methane production by anaerobic co-digestion of slaughterhouse with fruit and vegetable wastes. Avicenna J. Environ. Health Eng. 2016;3:e8541.

10. Hill DT, Cobb SA, Bolte JP. Using volatile fatty acid relationship to predict anaerobic digester failure. Trans. ASAE 1987;30: 496-501.

11. Alibaba.com. Scrubber tower packing price [Internet]. Scrubber: Packing; c2017 [cited 4 May 2017]. Available from: http//www.alibaba.com/trade/search?IndexArea=product_en \&CatId $=\& f s b=y \& S e a r c h T e x t=$ scrubber + tow $\mathrm{er}+$ packing\&viewtype $=\mathrm{G}$. 